\title{
TRANSPOSICIONES ENTRE CINE Y LITERATURA: AMÉRICA LATINA EN EL IMAGINARIO IMPERIALISTA ALEMÁN, 1890-1945
}

Transpositions between Literature and Cinema: Latin America in the German Imperialist Imaginary, 1890-1945

\author{
MARION BREPOHL ${ }^{\mathrm{a}}$ \\ Universidade Federal do Paraná \\ Conselho Nacional de Desenvolvimento Científico e Tecnológico-CNPq
}

DOI: $10.15366 /$ secuencias2020.52.001

\begin{abstract}
RESUMEN
Este artículo lleva a cabo un estudio sobre la circularidad entre imágenes y textos transmitidos en los medios de comunicación de la era Guillermina, la República de Weimar y el nazismo, basado en mitos literarios de fundación; entre ellos, destacan el migrante alemán y su encuentro con lo exótico. Al principio, examinamos los enfoques narrativos de algunas novelas de entretenimiento (o Trivialliteratur) cuyo escenario es América Latina o África, regiones entendidas como un "territorio vacío" a ser explorado por el migrante de origen germánico que busca expandir el espacio vital (Lebensraum). Luego, se observa cómo estos temas se transponen al cine en la época del nacionalsocialismo. Son imágenes que, apropiándose tanto de la novela de aventuras como de su audiencia, hacen uso de la figura del migrante, entendido en adelante como «alemán en el extranjero» (Auslandsdeutsche), como un héroe en el exilio, y de lo exótico, a su vez, como un espacio vacío de derecho, con el objetivo de gestar, a nivel de los afectos, el resentimiento por la derrota y la sacralización de la venganza.
\end{abstract}

Palabras clave: novelas de entretenimiento, cine de aventuras, nazismo, exótico, espacio vital.

\begin{abstract}
This article studies how images and texts were circulated in the media in Germany's Wilhelmine era, the Weimar Republic and the Nazi period, based on a number of foundational literary myths. Among the latter, we focus particularly on the trope of the German migrant and his encounter with the exotic. We will begin by looking at the narrative focus of several novels written for popular entertainment (or Trivialliteratur) and which take place in Latin America or Africa. These regions are signified as 'empty territory', as places to be explored by migrants of German origin who go in search of broader horizons to inhabit (Lebensraum). We then move on to look at how the same themes are transposed to national socialist cinema. These are images that, appropriating both adventure novels and its public, make use of the figure of the migrant, now understood as the «German living abroad» (Auslandsdeutsche), a hero in exile, as well as the notion of the exotic, as a space with no rights. Their objective is to generate, at an affective level, resentment over defeat and the sacralization of revenge
\end{abstract}

Keywords: Popular novels, adventures cinema, Nazism, exotic, living place.

[a] Marion BREPoHL es profesora titular de Historia Contemporánea de la Universidad Federal de Paraná e investigadora del Conselho Nacional de Desenvolvimento Científico e Tecnológico-CNPq. Doctora por la Universidade Estadual de Campinas-UNICAMP, realizó el posdoctorado en la Universidad Libre de Berlín y en la Universidad de Paris I-Sorbonne. Es coordinadora del Grupo Direitos Humanos e Politicas de Memória, con un proyecto financiado por el CNPq. Entre sus más recientes publicaciones destacan Imaginação Literária e política: os alemães e o imperialismo; Eichmann em Jerusalém; 50 anos depois, como coordinadora, y Políticas de memória e experiências de des-exilio, como organizadora (con Marcos Gonçalves). mbrepohl@yahoo.com.br 


\section{La novela de aventuras y el exilio cultural}

Cualquiera que haya pasado por una residencia de descendientes de alemanes en América Latina, desde finales del siglo XIx hasta la Segunda Guerra Mundial, encontrará, con toda probabilidad, un conjunto de libros de aventuras de autores nacidos y residentes en Alemania o de inmigrantes e hijos de inmigrantes que usaban el idioma alemán. Viajes peligrosos, hombres perdidos en la selva amazónica o en el desierto del Sahara, enfrentamientos con pueblos belicosos y animales salvajes. Todo aquello escenificaba un mundo lleno de peripecias, algo comparable a nuestras emociones cuando vemos hoy una película de aventuras como las de Indiana Jones, de Steven Spielberg; nos mordemos las uñas, cerramos los ojos y esperamos que el héroe triunfe.

Encontraría también almanaques que, además de información útil para el día a día de la familia y los negocios, publicaban cuentos, poemas y noticias del viejo mundo, así como noticias sobre la fauna y la flora del país que los acogió.

Muchas de estas lecturas pueden considerarse como Trivialliteratur o, en español, literatura ligera y de entretenimiento. Lejos de los cánones consagrados por la academia, estos escritos fueron, sin embargo, bestsellers que tuvieron un enorme impacto en el público lector. Trataban sobre la trayectoria de un individuo, generalmente voluntarista, célibe y valiente, proveniente de una familia común, sin muchas posesiones, por lo demás, sin muchas ambiciones y que, por causas casi accidentales, abandonó su tierra natal. Partió hacia lo desconocido, hacia territorios lejanos, donde se enfrentaría a hombres salvajes y naturaleza inhóspita. Como en las novelas inglesas, tan bien analizadas por Hannah Arendt, tales escritos inauguraron un nuevo género literario y, sobre todo, un nuevo público lector: personas sin mucho interés por la política, obsesionadas con sus necesidades materiales, desconectadas de la cohesión social, aisladas en sus hogares, dispuestas a imaginar cómo vencer en la vida, así como quien gana una apuesta ${ }^{1}$. Solitarios como Robinson Crusoe, empresarios de sí mismos, les resta arriesgarse a vencer; en el caso inglés, más que en ningún otro, la suerte se vislumbraba en ultramar.

En muchas novelas de aventuras en Alemania, un país de emigrantes, la suerte individual era a menudo proyectada e idealizada como aventura en el nuevo mundo. Escritos para el público juvenil, que vivía en su cotidianeidad cómoda y monótona, típicamente pequeñoburguesa, estos libros los hacían soñar e imaginar su vida en otras regiones, donde descubrirían lo exótico, la riqueza, la lujuria.

Citemos tres ejemplos paradigmáticos de esta literatura, así como sus autores.

El más famoso de ellos es Karl May (1842-1912), uno de los escritores de habla alemana más exitosos. Se estima que solo en Alemania vendió alrededor de ochenta millones de libros; la tirada universal ronda los doscientos millones. También es uno de los escritores más traducidos, con ediciones en cuarenta y seis idiomas ${ }^{2}$. Su importancia también radica en que sus libros sirvieron de inspiración para nada menos que veintidós películas de aventuras, desde el cine mudo hasta 1968, además de series de televisión (1963-1998) y una serie de animación (a partir de 2002).

Entre las aproximadamente ochenta novelas de aventuras de Karl May, el autor favorito de Hitler, me gustaría mencionar uno de sus temas principales: los indígenas en las Américas. El personaje más famoso de May es el indio semiario Winnetou, amigo, casi hermano menor del alemán Old Shatterhand.
[1] H. Arendt, O sistema totalitário (Lisboa, Dom Quixote, 1978), p. 204 y ss.

[2] M. Korfman \& R. Meneguzzo, «Encenações autorais e textuais em Karl May» (Pandaemonium ger, vol.20, n. ${ }^{\circ} 31$, São Paulo, julio/agosto 2017). 
[3] R. Ueding, Karl May Handbuch (Stuttgart, Alfred Kröwer Verlag, 1987).

[4] Karl May, Am Rio da Plata. (Bamberg, Am Rio da Plata, 1952 [1889]).

[5] M. Brepohl, Imaginação literária e política; os alemães e o imperialismo (Uberlândia, Editora UFU, 2010).

[6] Karl May, In den Kordilleren (Viena, Toso Verlag, 1962 [1891]).

[7] Priscilla Lopes d' E1 Rei, Maria Kahle (1891-1975): vida e obra (São Paulo, Instituto Martius-Staden, 2014). Disponible en: $<$ http://www.martiusstaden.org. br/conteudo/detalhe/135/mariakahle-1891-1975-vida-e-obra $>$.
El escritor sabía captar las pasiones de su época, cuando lo exótico se destacaba cada vez más en exposiciones etnográficas, narrativas, tratados científicos. Fue una época de expediciones científicas, expansión colonial, turismo y migración. Cuatro millones de alemanes emigraron de Alemania a Estados Unidos durante la vida de Karl May, y todos los que abandonaron su país lo hicieron con gran curiosidad por el Nuevo Mundo. Por ello, el viejo oeste sería revelado por un alemán de origen y destino desconocidos, siempre acompañado por el nativo Winnetou, un cacique inteligente y líder de su pueblo ${ }^{3}$.

Sin embargo, la representación del nativo es diferente en la novela del libro $\mathrm{Am}$ Rio da Plata,${ }^{4}$ que se desarrolla en América Latina. Allí, los indígenas son presentados como pueblo, sin que ninguna singularidad se destaque en ninguno de ellos, con la única excepción de una mestiza, que desempeña el papel romántico de la trama ${ }^{5}$.

En este libro, el héroe es un alemán, llamado Karl, de cuyas actividades (profesión, motivo del viaje, destino) siempre se sabe muy poco o casi nada. Soltero y, al principio, solitario, se convierte en personaje central por fuerza de las circunstancias y no por una intención deliberada. Viene a Latinoamérica para conocer sus costumbres y su paisaje. Es, por tanto, un viajero, entre investigador y turista, como tantos que desempeñan un papel relevante en la era de los imperios.

Por una cuestión de justicia, ayuda a un hispano-uruguayo, que le ofrece su amistad y se convierte en su guía. Ambos pasan entonces a ser víctimas de diversos ataques y amenazas, perpetrados por políticos corruptos y ladrones, siendo ayudados por la gente sencilla de la región, igualmente engañada y amenazada.

Karl, el héroe lleno de trucos, salva a todos sus amigos de los conflictos que enfrentan a causa de los hombres malos (el dominador español) y, con ellos, continúa su viaje hacia la búsqueda del tesoro, tema principal del segundo libro, In den Kordilleren $^{6}$. Allí entra en escena el ladrón de tesoros, un hombre que subyuga y engaña a los indios, aliándose con políticos corruptos. En el desenlace, este bandido muere y la catarsis se produce a través de la victoria del buen salvaje y el buen civilizador, sobre los malos salvajes y los malos civilizadores. No es el enriquecimiento lo que se presenta como premio a las buenas personas, sino la paz y la felicidad doméstica.

No menos importante es el personaje colectivo que subyace en la narrativa, silencioso, pero numéricamente expresivo: los inmigrantes alemanes, que llegan en paz para trabajar, un pueblo sin territorio en su país de origen que encuentra su nueva patria en la región del Gran Chaco. Sin hacer sombra a nadie, encuentran su lugar allí bajo el sol.

El segundo ejemplo es una novela de Maria Kahle (1891-1975), menos por su fama, porque no era tan representativa como May, sino por su carrera como escritora y militante del Partido Nacionalsocialista; la cito, también, por el hecho de que dio charlas y conferencias en Brasil sobre la nueva Alemania de los años veinte, al servicio de la Compañía Bayer, como, de hecho, varios agentes culturales lo harían por toda Latinoamérica, difundiendo no solo la literatura, sino también el cine alemán.

Maria Kahle era una periodista comprometida con la antidemocrática y antisemita Orden «Jóvenes Alemanes» (Jungdeutscher Orden), que mantenía un periódico titulado Der Jungdeutsche («El joven alemán») en la ciudad de Kassel. Allí permaneció de 1924 a 1926. Luego continuó sus estudios hasta que, en 1934, con el ascenso nacionalsocialista, Kahle se unió al NSDP, para el cual realizó un viaje de propaganda partidaria en Sudamérica, permaneciendo en Brasil hasta el fin de la guerra ${ }^{7}$. 
Sin embargo, a partir de 1942, debido a una grave enfermedad, reduce su actividad literaria y regresa a Alemania, donde comienza a dedicarse a la literatura infantil.

$\mathrm{Su}$ carrera como escritora comienza con el registro de sus impresiones de la estadía en Brasil, con poemas con un sesgo lírico-religioso y naturalista. Sus obras de las décadas de 1920 y 1930 tematizan con frecuencia el crecimiento de la población alemana en tierras extranjeras y también describen, no pocas veces, su tierra natal en Westfalia.

En una de sus novelas, titulada Siedler in Itajahy («El colono de Itajaí»), narra la saga de tres generaciones de una familia que migra a Blumenau; son personas sencillas, pobres, trabajadoras y valientes, inspiradas por el espíritu comunitario y tradicionalista. La madre, matriarca de la familia, es el yo narrador; ama a su país natal, pero acepta su destino de emigrar, aunque siempre tiene la esperanza de su regreso.

Con la derrota en la Primera Guerra, ese sueño parece desvanecerse, porque la Alemania derrotada está destruida. Sin embargo, después de unos años, las constantes noticias sobre las dificultades de su país de origen inspiran a familiares y amigos a luchar por la restauración del honor de su pueblo, ya que, hasta entonces, se habían librado de las atrocidades cometidas contra sus hermanos. Esta toma de conciencia se da en el momento en que el miembro más joven de la familia decide emigrar a Alemania, pues esta vez, como sabían, había un líder allí para llevarlos a la unidad. La dama acepta valientemente el destino del niño y considera que:

\footnotetext{
Alemania tiene derecho a sus hijos, incluso a los que están lejos; ella siempre será nuestra madre, porque nos dio el alma, la sangre y nuestro carácter ... una madre que tiene el poder sobre nuestros sueños ... y en ellos, ella nos llama. ${ }^{8}$
}

Finalmente, el tercer ejemplo, que se aproxima, o incluso se amalgama, con la desventura del inmigrante alemán: Volk ohne Raum («Pueblo sin espacio»), de Hans Grimm (1875-1959).

Sobre el autor puede decirse que Grimm tuvo una infancia tranquila, era tímido y retraído, lo que lo llevó a refugiarse en la literatura. Pero, debido a la imposición de su padre, trabajó en el área comercial, en virtud de lo cual permaneció por doce años en Sudáfrica. Quizás haya sido esta estadía la que lo inspiró a escribir su novela más famosa, que incluso se convirtió en una lectura obligada en el Tercer Reich.

En Volk ohne Raum, ${ }^{9}$ un libro de mil trescientas páginas publicado en 1926, cuenta la saga de dos amigos que, sin posibilidades materiales en su propio país, van a probar la vida en Sudáfrica. Una vez que llegan, se encuentran con los diferentes grupos que ocupan la región: los boers, los colonos alemanes, los xhosa y los bosquimanos. Consiguen, a pesar de los duros contratiempos, realizarse como agricultores en el África del Sudoeste alemán llevando una vida impecable, tanto desde el punto de vista moral como en el trabajo.

La elección de la región no fue obviamente accidental: fue un protectorado alemán entre 1894 y 1917, el más exitoso desde el punto de vista de establecer una población blanca oriunda de Alemania. Por eso, tampoco es casual que el joven Friebott, protagonista de la novela, viva allí y sea después obligado a regresar a Alemania, donde pasa a narrar los sufrimientos de los alemanes. Concluye que es necesario ampliar el espacio vital (Lebensraum), reconquistando las colonias en África.

El título de la novela se utilizó como eslogan en la República de Weimar, debido
[8] Maria Kahle, Siedler am Itajahy. (Reutlinien, 1938). (La traducción es nuestra).

[9] Hans Grimm, Volk ohne Raum. (Albert Langen, 1926). 
a que el Tratado de Versalles había privado a Alemania de su imperio colonial. Ese período fue entendido como un período de pobreza, miseria, hambre y superpoblación. Estrechamente vinculada a esta idea estaba la afirmación de que la tierra había sido injustamente dividida entre las grandes potencias, dejando a los alemanes con muy poco en comparación con las naciones europeas menos pobladas.

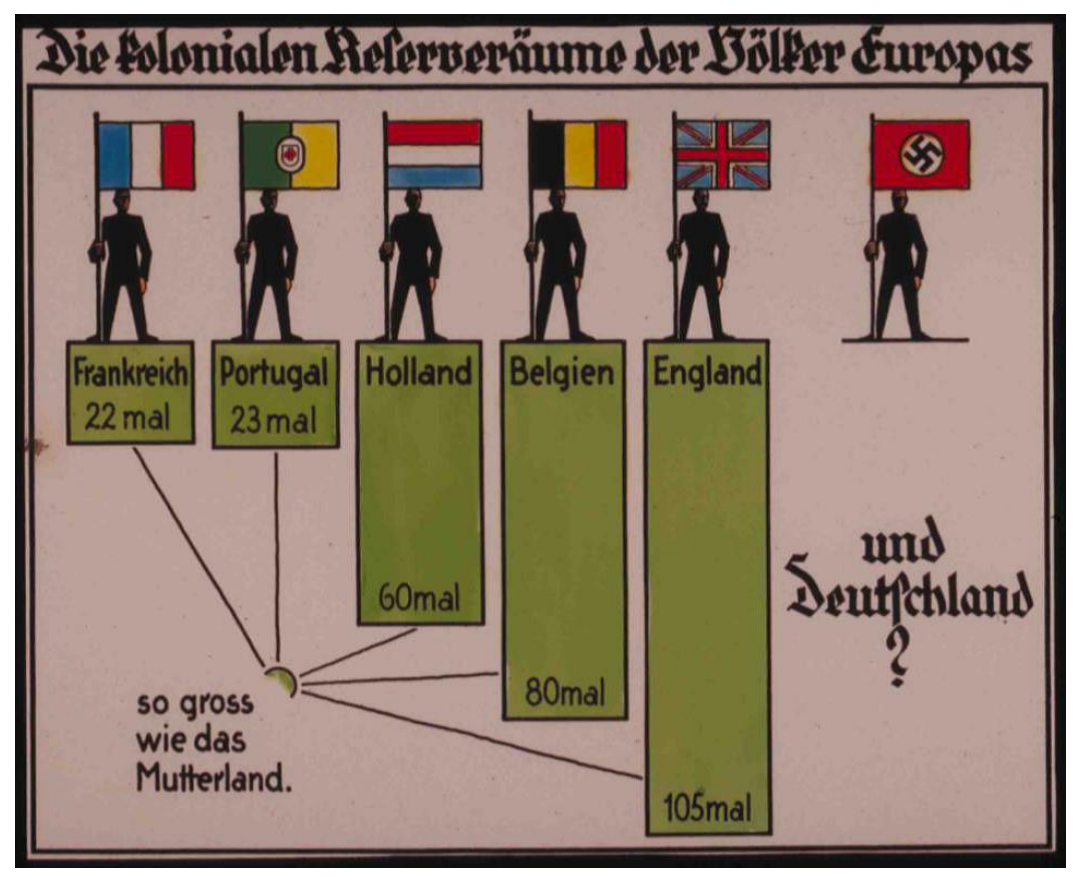

Propaganda que emula el eslogan inspirado en el libro de Hans Grimm. Traducción: «Las reservas coloniales de los pueblos de Europa - Tamaño relativo a la madre patria! Francia: 22 veces. Portugal: 23 veces. Holanda: 60 veces. Bélgica: 80 veces. Inglaterra: 105 veces. ¿Y Alemania?». Fuente: Sociedad Colonial Alemana, tomado de N. Krachenski Stadler, Em busca das colônias perdidas; a visualidade da propaganda do Movimento Neocolonial Alemão (1925-1943), p. 65)

Este libro, que popularizó el concepto de Lebensraum, fue el único que se presentó en la feria mundial del libro de Chicago en la época del nazismo. Y Hans Grimm, a pesar de no haberse afiliado al Partido Nazi, participó en varios eventos alusivos al movimiento. Su patriotismo y resentimiento ante la derrota en ambas guerras lo acompañaría hasta el final de su vida.

Delineados los principales focos narrativos de los tres libros, podemos identificar sus denominadores comunes; aunque en diferentes escenarios, estas tres novelas crean y recrean un tema recurrente del romanticismo tardío alemán: «la gente, la sangre, la tierra», es decir, el espacio vital. En ellos, el artesano o agricultor es decente, fiel y diligente y se encuentra a merced del especulador, el gran industrial y el buitre lucrativo. El trabajo asalariado urbano se contrasta con el valor agregado honesto a través de la agricultura, la ganadería y la artesanía. La caracterización de los colonos alemanes es étnica, lo que a su vez les define una ética, anteponiéndose, diferenciándose de los demás; ellos son lo contrario de los voraces boers, los caudillos crueles, los portugueses sin afición por el trabajo manual, de los ingleses mentirosos. 
Hay una obsesión por narrar las diferencias entre los pueblos originarios, es decir, la etnografía en plena fase de autoconsagración como ciencia. Por ende, estos son casi siempre presentados como pueblos necios, pero no violentos ni promiscuos, vicios atribuidos a los blancos.

El adversario del alemán y, asimismo, de la felicidad y armonía es el blanco europeo, no el nativo. El nativo parece que será naturalmente tutelado, porque los alemanes no quieren lucrarse ni pretenden explotarlos, sino que, estando a su lado, los civilizan, como hiciera Old Shatterhand con Winnetou, dejando intacto su poder de cacique.

En estas narrativas, el espacio vital se convierte en un derecho a ser conquistado por el alemán en el exterior, como lo hicieron otros pueblos.

Sin embargo, Lebensraum no era una idea nueva, nuevos eran los vehículos a través de los cuales se difundía: la Trivialliteratur, el cine, los afiches publicitarios, las infografías, todos ellos en proceso de retroalimentación.

Lebensraum se remonta a 1870 , un concepto clave de uno de los movimientos pan más agresivos de la era de los nacionalismos, el pangermanismo. Se diferenciaba, por ejemplo, del paneslavismo y el panamericanismo, que pretendían la reunión de varias etnias y hablantes de diversos idiomas en torno de una autoridad aclamada por sus activistas; en cambio, la Liga Pangermánica, alentaba un movimiento de unificación basado en la uniformidad étnica y la jerarquización de todos los pueblos a partir de la noción de superior-inferior.

De acuerdo con Louis Snyder:

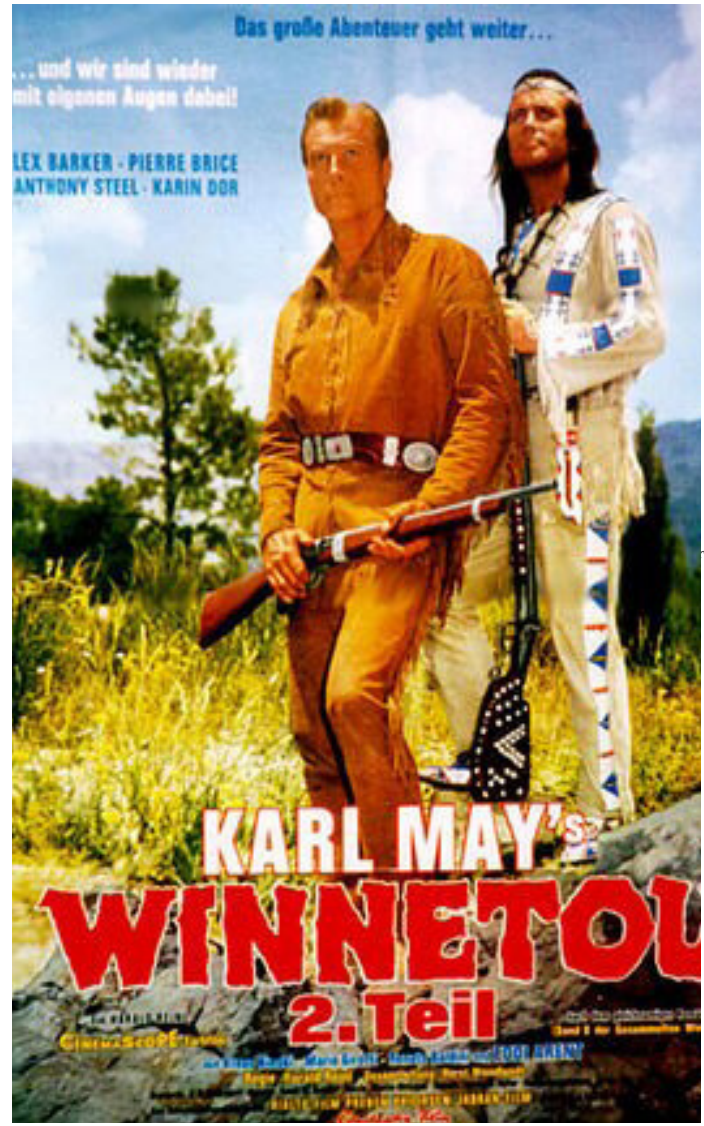

Afiche del film Winnetou II (1964), dirigido por Harald Reinl, con Lex Barker y Pierre Brice. Estrenado en España con el título Carabina de plata, en México, Venezuela y Panamá como Furia Apache y en Chile, Argentina y Colombia como Winnetue: La furia de los apaches.

\begin{abstract}
De los conservadores, los pangermanistas se dejaron orientar por valores tradicionales como la jerarquía, superioridad biológica, imperativo territorial, la veneración de lo nacional sobre lo internacional, la concepción de casta en vez de clase y la veneración de la autoridad, la autoridad magistral. Ellos rechazaban el racionalismo del Iluminismo, despreciado como invención de los judíos. Más importante, a sus ojos, era la intuición, el radicalismo de derecha y el fanatismo revolucionario. Ellos despreciaban el conservadurismo moderado por irrealista y ridiculizaban su defensa de la ley, el orden y la estabilidad. Para los pangermanistas, solo una adaptación conservadora extremista tenía sentido. ${ }^{10}$
\end{abstract}

Diversos estudios dedicados al pangermanismo llaman la atención sobre la apelación a la unificación de pueblos vistos como germánicos (y más tarde, arios) en un solo país y con un único jefe. Se trataba de una propaganda cuyo público objetivo eran residentes de origen alemán que vivían en regiones de Austria, Hungría, Francia, Checoslovaquia y otras, con la intención de ampliar las fronteras de lo que sería
[10] Louis L. Snyder, Macro nationalisms: A History of the Pan-movements (Londres, Greenwood Press, 1985. p. 43). (La traducción es nuestra) 
[11] Marion Brepohl, Pangermanismo e nazismo; a trajetória alemã rumo ao Brasil, p. 75

[12] Alemania perdió todas sus colonias en la Primera Guerra Mundial, pero, en algunas regiones, la población de origen germánico mantuvo la residencia, no retornando a su país de origen.

[13] Hannah Arendt, Origens do totalitarismo... p. 302 y ss.

[14] Carl Schmitt, El nomos de la tierra (Buenos Aires, Ed. Struhart, 2005 [1950])

[15] Marion Brepohl. «Dever de memória e colonialidade: a invisibilidade dos subalternos», en Marcos Gonçalves y Marion Brepohl, Politicas de memória e experiências de (des)exilio (Curitiba, Editora da UFPR, 2017), p. $89-110$.
Grossdeutschland. Esto no se limitaba a los países vecinos, sino que también alcanzaba a América Latina. En diversas regiones de este subcontinente, nacionalistas alemanes soñaban con crear una colonia alemana, ya fuera por la fuerza (anexión de territorios en Argentina, Brasil, Uruguay, Paraguay y Chile) o por el nacionalismo de los Auslanddeutschen (alemanes residentes en el exterior), que siempre otorgarían, así lo suponían, una preferencia económica a los negocios con empresas alemanas. Apenas como ejemplo, cabe señalar que, en Brasil, la Liga Pangermánica reunió a seis mil miembros que fueron responsables de diversos acuerdos comerciales e intercambios de carácter religioso y/o cultural en la Región Sur, llegando también a Argentina, Uruguay y Chile. ${ }^{11}$

También en África, donde Alemania tuvo colonias durante aproximadamente treinta años, se estableció una población de origen alemán que creó asociaciones vinculadas al país de origen, dedicadas a la preservación de su cultura, idioma y costumbres. Incluso después de la separación de la metrópoli, esta población siguió ligada a sus orígenes. ${ }^{12}$

Este sentimiento de pertenencia a una comunidad ampliada, que Arendt llamó nacionalismo tribal, ${ }^{13}$ estaba asociado a imágenes idílicas del emigrante alemán como alguien apegado al medio rural, a los valores campesinos, a la moral del trabajo. Tal idealización habla poco de otro factor que no comienza en la Segunda Guerra Mundial, pero que se nutre de la experiencia de otras coyunturas de la era de los imperios: Lebensraum implicaba, desde el comienzo, un Todesraum (espacio de la muerte).

Desde los años veinte del siglo pasado, el jurista Carl Schmitt, tomando la expansión europea como punto de partida, había declarado que el espacio no europeo era un espacio vacío de derecho y que la dominación - en este caso, el dominio de estados fuertes sobre territorios no ocupados - garantizaría el equilibrio de fuerzas, es decir, la paz en el espacio intraeuropeo. Después de todo, según él, desde las primeras conquistas de ultramar, cualquier territorio no europeo había sido considerado un espacio de apropiación. Por esa razón, el otro no podía ser considerado adversario o vecino, sino sujeto hostil a ser despojado, enemigo, no porque fuera malo en sí mismo, sino por resistente al ensanchamiento de la frontera que pretenden los más fuertes. ${ }^{14}$

Las ideas de Schmitt se basan en diversos ejemplos de los siglos anteriores, llevando a otra práctica, que da lugar al establecimiento de espacios de muerte; en el siglo xix, se observa una serie de masacres de pueblos originarios a las que siguió el asentamiento de la población blanca. Menciono cuatro de los más importantes: la expulsión o masacre de indígenas en la región hoy llamada Blumenau, entre 1850 y 1914, en un proceso de vaciamiento demográfico para la posterior ocupación del territorio con inmigrantes alemanes; la pacificación de la Araucanía, nombre que los españoles dieron a los conflictos que llevaron al exterminio de buena parte de la población mapuche, en la Región Sur de Chile (1862-1883), que se hizo para favorecer el asentamiento de migrantes germánicos. También en Argentina, en las regiones de Patagonia, El Chaco y Misiones, la mayoría de este contingente sufrió varios ataques, siendo el más notable el que se conoció como la Conquista del Desierto, ocurrida en 1870, donde se trasladaron inmigrantes de origen germánico con el objetivo de desarrollar la agricultura. Y el genocidio del pueblo herero, en la región ahora llamada Namibia, por parte de tropas alemanas, adonde fueron los colonos de la República de Weimar. ${ }^{15}$ Territorios con un clima templado, de fácil adaptación para el europeo, 
suelo para cultivo y no solo para extracción, he ahí el deslizamiento de Lebensraum, Entvölkerung, Todesraum.

\section{La aventura y lo exótico en el cine}

En el siglo xx, con el auge del nazismo, la idea fuerza del Lebensraum se traslada desde ultramar hacia el interior de Europa. Hubo un breve intento por parte del gobierno de recuperar las colonias perdidas, a través de Kolonialpolitisches Amt, en 1941, pero este intento pronto fue abandonado. El locus privilegiado para la expansión del espacio vital pasó a ser Europa del Este y no África o América Latina, aunque insistieran en la propaganda expansionista entre los descendientes de alemanes en esos territorios, con el objetivo de fortalecer los lazos culturales y comerciales.

La primera invasión de las tropas nazis se dirigió a Checoslovaquia, en nombre de la anexión de los Sudetes; recordemos que Checoslovaquia fue inmediatamente declarada un protectorado, término tomado del Derecho Colonial; después, la invasión de Polonia, donde se instaló el campo de concentración más importante, lo cual ya había sido hecho en Sudáfrica por los ingleses y después por los alemanes en Namibia, donde se practicó el primer genocidio del siglo xx en 1906.

Heydrich Muller, nombrado gobernador de Checoslovaquia, no tenía dudas sobre su objetivo: «Toda esta región algún día será definitivamente alemana, y los checos no tendrán nada que hacer aquí» ${ }^{16}$. Aproximadamente dos tercios de la población eventualmente serían trasladados a las regiones de Rusia o exterminados tras la victoria de la Alemania nazi en la guerra. Bohemia y Moravia serían anexadas por el Reich alemán.

Impusieron a los checos el trabajo forzado. Más de cien mil trabajadores fueron retirados de puestos de trabajo «inadecuados» y reclutados por el Ministerio de Trabajo. Y la jornada laboral pasó de ocho a doce horas diarias a partir de febrero de 1942.

La masacre más conocida, incluso por la propaganda realizada por el propio gobierno nazi, fue la que prácticamente hizo desaparecer la pequeña localidad de Lídice, que fue cercada por tropas nazis, impidiendo la salida de los residentes. Todos los habitantes varones mayores de dieciocho años fueron separados de las mujeres y los niños, confinados en un granero y fusilados en pequeños grupos al día siguiente. Las mujeres y los niños de la ciudad fueron enviados al campo de concentración de mujeres de Ravensbruck, donde la gran mayoría eventualmente moriría de tifus y agotamiento por trabajos forzados. El modelo era, por tanto, una colonia con trabajo forzoso, con el exterminio de parte de los presos, algo parecido a lo que se hizo en Namibia, en la época de los conflictos con el pueblo herero y el pueblo nama. Es muy similar a lo que se presentó en la película Ohm Krüger (Hans Steinhoff, 1941), como veremos a continuación.

Pero si bien sabemos que Europa del Este era el espacio pretendido por Hitler, África y las Américas, como residencia de Auslandsdeutschen (alemanes en el exterior), ${ }^{17}$ no dejaban de ser recordadas y valoradas, aunque no fuese más que por el interés económico y cultural de esta población. La influencia alemana ya era una constante en estas regiones, dada la facilidad del idioma y el relativo éxito de los empresarios de origen alemán; con el ascenso del nazismo, una minoría se afilió al partido o simpatizó con el régimen, con la esperanza de volver a Alemania o al menos
[16] A. Nebe. «Das Spiel ist aus» (Der Spiegel, 9/02/1950). Disponible en: $<$ https://www.spiegel.de/ spiegel/print/d-44446464.html> . $(12 / 09 / 2019)$

[17] El término sustituyó, en el período nazi, a la identidad «con guion» de los inmigrantes y sus descendientes; en vez de teuto-argentinos, teuto-namibiaos, teuto-brasileños y otros, pasaron a autodesignarse, todos ellos, como alemanes en el exterior. M. Brepohl. Pangernismo e nazismo; a trajetória alemã rumo ao Brasil (Curitiba, SAMP, 2014). 
de aprovechar el «nuevo orden».

Antes de ocuparnos de este imaginario, consideremos que, cuando asociamos nazismo y cine, escenas de calumnias contra los judíos, mítines a favor del Führer, banderas desplegadas con la esvástica y documentales de guerra son inevitablemente casi las únicas que se nos ocurre. Nuestra memoria evoca repetidas y aburridas escenas del Führer, sus marchas y discursos, haciéndonos creer que solo esto fue presentado al público.

No eran esas exactamente las películas que arrebataban a la audiencia. Las parejas románticas y las melodías sentimentales, así como la naturaleza y la historia romantizada y pasteurizada, eran leitmotiv recurrentemente accionados. Y, como en la novela de aventuras, su antecesora, el cine alemán también buscó atraer al público a través de imágenes de ultramar, en montañas, campos y selvas, donde parejas románticas u hombres solitarios y valientes arriesgaban su suerte. Entre los escenarios más atractivos estaba lo exótico, que seguía siendo una faceta sublimada de lo erótico.

Según Pereira, con la transformación del cine en política estatal, la Ley Nacional de Cine introdujo en Alemania un nuevo sistema de distinciones (Pradikäte) para las películas, a partir de las cuales los autores podían obtener premios y exenciones:

Cine nacional, (Film der Nation, 1939); política y artísticamente de valor especial (Staatspolitisch Wertvoll und künstlerisch besonders Wertvoll, 1933); en particular, valioso para la política de estado, (Staatspolitisch besonders wertvoll, 1933); de especial valor artístico (Künstlerisch besonders wertvoll, 1933); culturalmente valioso (Kulturell wertvoll, 1933), valioso para el pueblo (Volkstümlich wertvoll, 1939), (...), valioso para la juventud (Jugendwert, 1938) ${ }^{18}$.

Es cierto que tales clasificaciones eran, en mayor o menor medida, temáticas, porque todas las películas pasaron por el tamiz de la propaganda oficialista. Sin embargo, nos detendremos en algunos aspectos que, en cierto modo, reflejan la puesta en escena, la circularidad y las apropiaciones de los temas vinculados a la literatura de entretenimiento asociada con lo exótico.

Sería imposible citar todos los casos, porque, de una manera u otra, dichos mensajes terminan por diluirse. Por esta razón, decidimos seleccionar algunos ejemplos que apuntan al resentimiento de los emigrantes, representados como exiliados culturales (por cierto, prácticamente todos los alemanes en el extranjero fueron presentados como exiliados, porque uno no deja de ser lo que es, alemán, la única identidad que importa), al ethos del judío y del inglés, antagonistas del idealismo alemán, y a lo exótico, entrelazado con lo erótico, en un tiempo prohibido y revelado en lo fugaz. Otro factor definió nuestra elección: el hecho de que son escenas de películas inspiradas en hechos históricos, distorsionados e instrumentados por y para la propaganda nazi.

Empezamos con Kautschuk (Eduard von Borsody, 1938) ${ }^{19}$ recomendado por su

[18] W. Pereira. O império das imagens de Hitler: O projeto de expansão internacional do modelo nazi-fascista na Europa e na América Latina; 1933-1955 (Tesis doctoral, São Paulo, Universidade de São Paulo, 2008), p. 99.

[19] Producido por la Universum Film Aktien Gesellschaft - UFA. valor artístico y político. La película se desarrolla en la región del Amazonas, donde un joven inglés busca, en 1876, contrabandear semillas de caucho para llevarlas a las colonias británicas. En virtud de la legislación brasileña, ese delito se castigaría con la pena de muerte si las autoridades se enteraran.

Desde su viaje a Brasil en barco, el joven aventurero Henry Wickham se enamora de la plácida Mary, joven inglesa que regresaba a Pará con su padre para conocer al fazendeiro Don Alonso, con quien se irá a casar. 
Aún con dificultades y sospechas, el inglés, protagonista ambiguo de quien no se comentan las malas intenciones (al fin y al cabo, es valiente y fuerte, como se exige a un hombre de los imperios), comienza su expedición con la ayuda de un nativo, José, que constituye el nexo con los demás nativos, todos negros, empleados de Don Alonso. Se hacen amigos, aun cuando esto sucede bajo la tutela de los ingleses.

Después de muchas aventuras, cuyo punto culminante es la lucha de Enrique con los feroces animales y los nativos, el protagonista logra escapar de Brasil con sus preciosas semillas, no sin antes dar un golpe a Don Alonso, que prefiere dejarlo ir para deshacerse de su rival.

El aspecto político, el monopolio de una materia prima, la codicia de los ingleses, la dudosa moralidad de Don Alonso, todos estos aspectos de la trama pasan a un segundo plano frente a las escenas de serpientes, cocodrilos gigantes, indios belicosos y sensuales danzas de nativos negros, que, aunque son empleados de Don Alonso, parecen no trabajar, sino solo beber y divertirse. En cuanto a los blancos, siempre están en el interior, usando ropa típicamente europea que no coincide con el calor de los trópicos.

Al final, se concluye que Brasil ha perdido el monopolio del caucho a favor de un país ya muy rico, gracias a la astucia de un inglés y a la debilidad moral de un brasileño apasionado; pero nada de esto importa demasiado: en la selva no hay que cumplir ninguna ley, y el héroe está luchando en la codiciada Amazonia. ${ }^{20}$
[20] La selva fue tematizada por varios escritores de la era de los imperios, como Conrad, crítico del imperialismo, en El corazón de las tinieblas. Sobre la selva amazónica cabe citar a Alfred Döblin, que tenía una postura diametralmente opuesta a la de los nazis. Había escrito una novela que presentaba este lugar como un escenario fantástico de sueños y misterios que es invadido por el europeo, quien se siente allí con la libertad para matar y destruir a voluntad. Amazonas Trilogie (Munich, Deutsches Taschenbuch, 1991 [1937-1938])

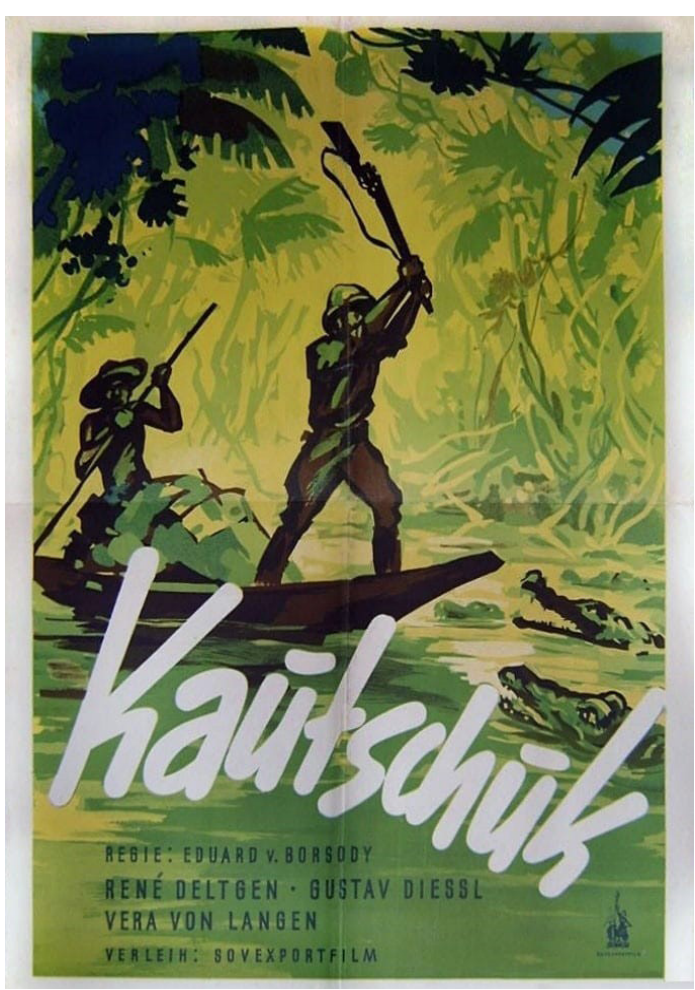

Póster de propaganda del filme Caucho (Kautschuk, Eduard von Borsody 1938). El protagonista inglés enfrentando cocodrilos con su fiel amigo José, que se expresa en alemán o portugués.

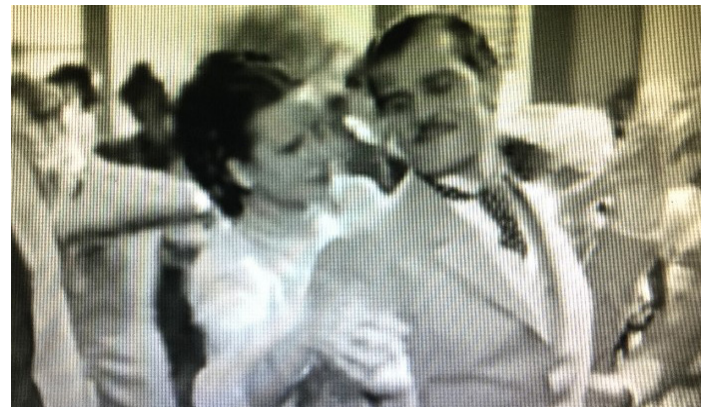

El baile comedido y elegante en un baile de blancos europeos en Belén de Pará, con la protagonista feminina Mary y el explorador inglés Henry. Fotograma de Caucho.

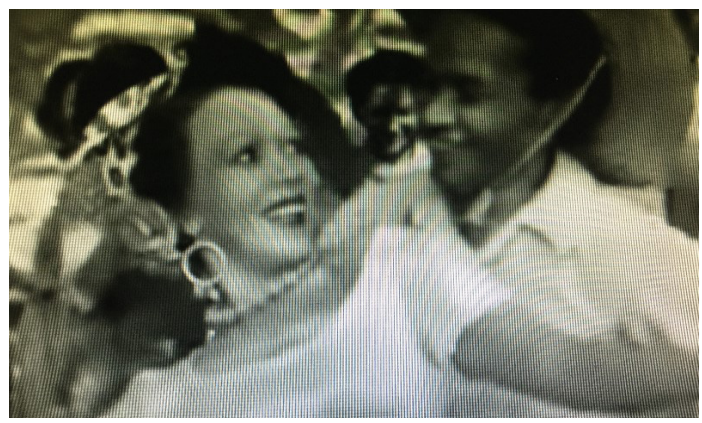

Y el baile al aire libre de los nativos, en que la mujer disfruta bailando, siguiendo sus instintos, con José, el amigo de Henry. Fotograma de Caucho. 
[21] Producida por Bavaria.

[22] Balder Olden, Paradiese des Teufels; biographisches und autobiographisches Schriften und Briefen aus dem Exil (Berlin, Rüten\& Loening, 1977 [1940]).

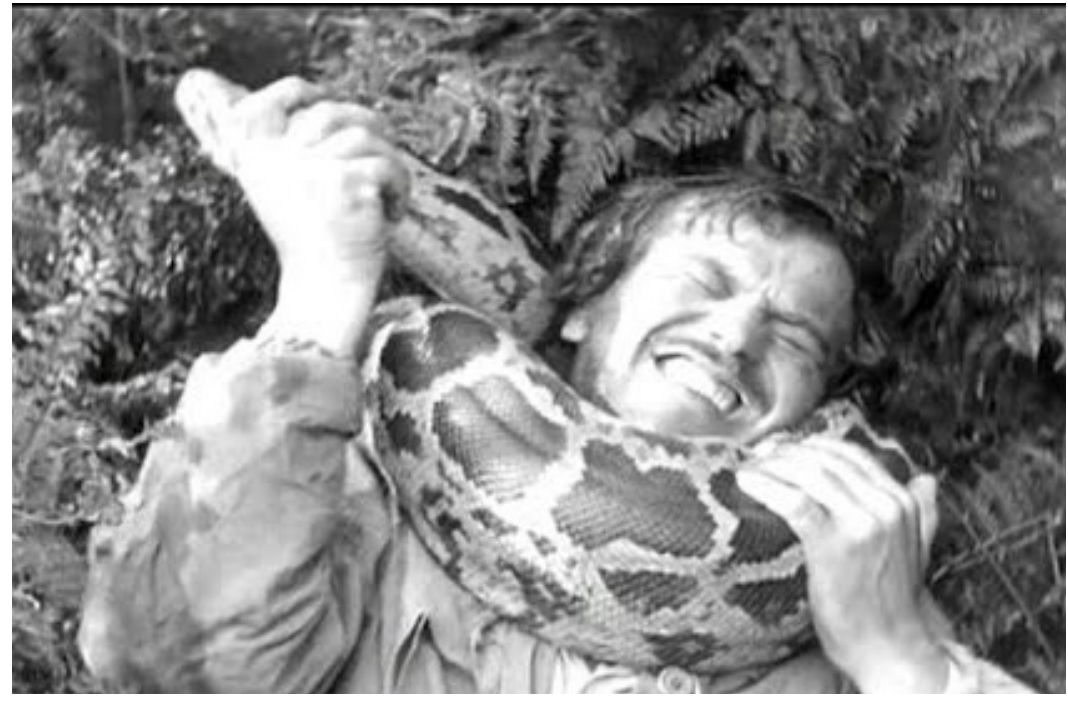

Escena del protagonista de Caucho, el inglés Henry Wickham, luchando contra una boa constrictor. Será salvado por su amigo nativo José, quien a su vez es salvado por Harry de ahogarse en el pantano.

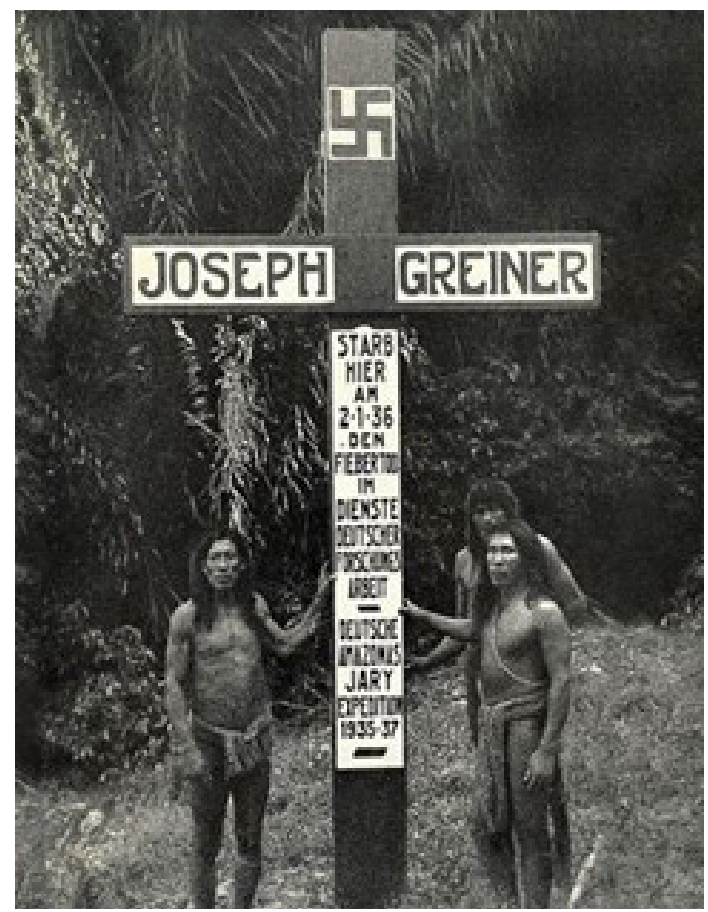

Fotografía del lugar donde fue enterrado Joseph Greiner en la selva amazónica. Escrito en la cruz: «muerto de fiebre cuando estaba al servicio de la investigación alemana- Expedición Jary teuto-Amazonas - 1935-37» Fuente: Jens Glüsing, Das Guyana-Projekt (Berlin, Ch. Links, 2008). (tapa)
Curiosamente, en este mismo período, la Organización Extranjera Alemana del Partido Nazi (Auslandsorganisation der NSDP) envió una expedición a la Amazonia brasileña, en apariencia de naturaleza meramente científica, que más tarde se convirtió en un documental. En otras palabras, el espíritu aventurero correspondiente a la imagen de los británicos parecía transponerse en la práctica nacional-socialista, tanto en el plano de la ficción como en el plan estratégico del partido gobernante.

Carl Peters (Herbert Selpin, 1941) ${ }^{21}$ es la segunda película que hemos destacado: se inspira en un personaje celebrado por los historiadores nacionalsocialistas como una de las figuras más notables de la República de Weimar.

Agente colonial que gobernó el África oriental y que fue procesado y despedido, en parte, por su extrema truculencia hacia los nativos (a pesar de que las prácticas violentas en las colonias eran habituales), era alguien a quien el escritor Balder Olden llamó «un Hitler antes que Hitler» ${ }^{22}$. Con el ascenso del nazismo, su imagen es rescatada como la de un héroe, habiendo sido incluso honrado por la asociación de historiadores alemanes.

Peters, a quien le molestaba su baja estatura y su cuerpo débil, fue interpretado nada menos que por Hans Albers (1891-1960), la estrella más seductora y popular de este período. 
En el marco de las directivas del régimen, la película tiene valor artístico, histórico y juvenil. Pero también es una película que celebra lo exótico, con numerosas escenas similares a las de Tarzán de los monos, de W. S. Van Dyke (Tarzan the Ape Man, 1932). Y, tal y como Robinson Crusoe y Friday, Old Shatterhand y Winnetou o Henry Winkham y José, aquí también tenemos la pareja europea/nativa, compuesta por Peters y Ramnasan, aunque Peters no muestra mucha proximidad con el chico, quien, a su vez, es mucho más servil que los anteriores.

La inspiración viene, como ya se ha mencionado, de un personaje histórico, pero la atracción de la película fue la belleza de Albers, un personaje que representa al hombre fuerte y decidido que se aventura en la selva.

Carl Peters transcurre en el año 1892, cuando el protagonista, que siempre usa la expresión «Ich bin $i c h »$ («ese soy yo» o «yo soy yo», para expresar su altivez) insiste en que las autoridades alemanas apoyen sus proyectos. Estos nacen de una observación altruista, que ya se presenta al principio de la película: Peters, al final de sus estudios universitarios, llegando a Berlín con su amigo Carl Jühlke, ve en la estación de tren a un grupo de alemanes pobres que se van a América y concluye que Alemania está perdiendo lo mejor de su sangre. Por esta razón, proyecta otro futuro para el país, que es la conquista de colonias en África.

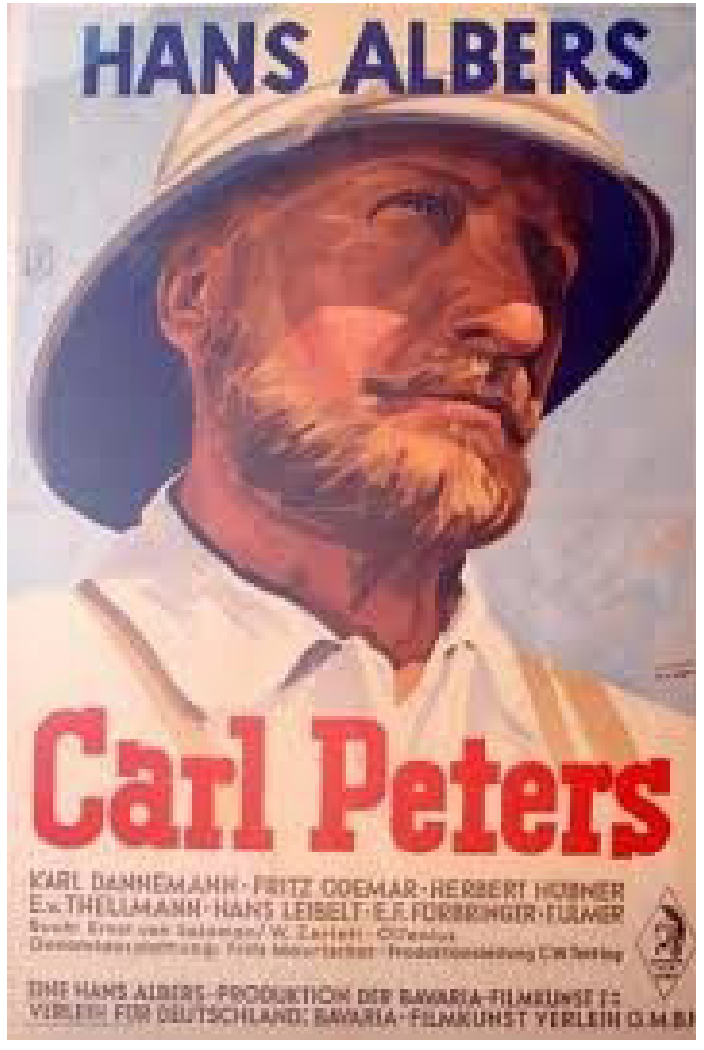

Póster de propaganda del filme Carl Peters (Herbert Selpin, 1941).

Incluso con poca ayuda, el héroe visionario parte con tan solo dos amigos a Zanzíbar, y de allí viaja al interior, ya con innumerables sirvientes nativos, donde cierra acuerdos comerciales con los líderes tribales locales, antes de que los británicos o los belgas puedan hacerlo.

Carl Peters sobrevive a una enfermedad tropical y a un intento de envenenamiento, resistiendo a todo y a todos; finalmente, recibe una carta del Káiser Guillermo garantizando la protección de su colonia, pero es ahí donde comienza su persecución, no solo de los británicos, sino también del jefe del Departamento Colonial del Ministerio Imperial de Asuntos Exteriores, que es judío.

La base de su condena es que asesinó a nativos, un hecho que corresponde a la biografía de Peters. Fue denunciado en el Parlamento por colgar a su concubina de quince años y a su sirviente doméstico. ${ }^{23}$ En la película, sin embargo, este episodio es retocado: lo que hizo fue vengar la muerte de su mejor amigo, perpetrada por dos hombres negros asesinos a instancias de los enemigos del Reich, cuya complicidad con los políticos socialdemócratas es evidente. Consciente de la trampa, asume su propia defensa en el Parlamento y, con gestos indisimuladamente idénticos a los de Hitler, habla a favor de África y luego renuncia voluntariamente.

La última escena de la película es con su madre, que lo abraza y le pide que vuelva a casa.

Por lo tanto, la trama está estrechamente relacionada con el resentimiento por la pérdida de las colonias alemanas o, más bien, con la incapacidad de la República

[23]Sobre la vida de Carl Peters se realizó un documental que podemos considerar de vanguardia, en 1978, por P. Heller, Die Liebe zum Imperium, que intentó justamente desmitificar la imagen del agente colonial. 


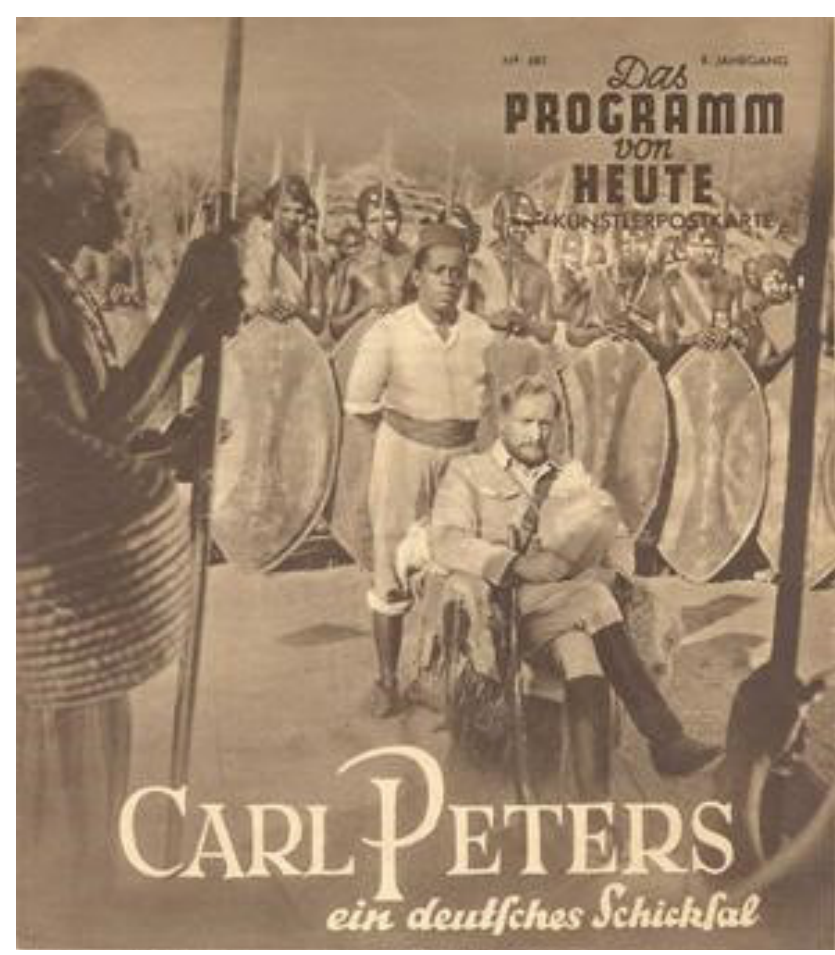

Póster de propaganda del filme Carl Peters (1941). Escena con nativos al fondo y en primer plano Peters y su fiel criado Ramasan, encarnado por el actor Mohamed Hussein, quien sería internado en el campo de concentración Sachsenhausen, donde murió en 1944, acusado de haber abusado sexualmente de una mujer aria.

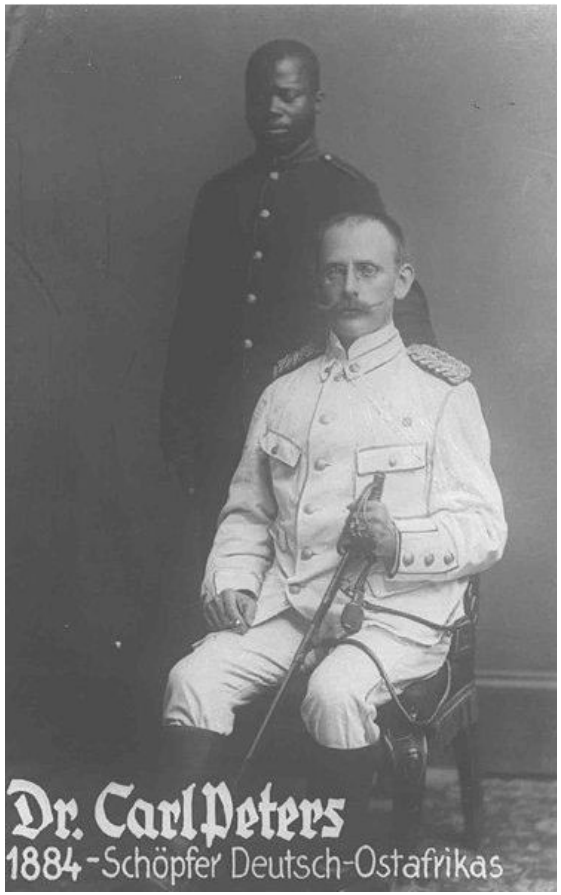

Foto más conocida del agente colonial Carl Peters, con su criado doméstico, a quien ahorcó por haberle robado un cigarro. Fuente: Carl Peters, Das Leben eines deutschen Kolonialisten (Rostock, Neuer Hoschulschriftenverlag, 2000) (foto de portada).
[24]Producida por Tobis Tonbild-Syndikat.

[25]Francis Coutarde y Pierre Cadars, Histoire du cinéma nazi (Paris, Eric Losfeld, 1972), p. 81. de Weimar para mantenerlas, así como también con la culpa de los comunistas y los judíos por oponerse al expansionismo; pero la mirada también está orientada hacia el futuro, ya que la obra de Peters se consuma con la ampliación del espacio vital realizada en el mismo momento en que se hace la película; a fin de cuentas el país está en guerra a favor de la expansión. No por casualidad, la última escena proyecta al fondo el Monte Kilimanjaro, hacia donde él y su madre, abrazados y de espaldas a la cámara, caminan hasta desaparecer.

La tercera película que mencionaremos, Ohm Krüger (Hans Steinhoff, Herbert Maisch y Karl Anton, 1941) ${ }^{24}$, reúne, según nuestra lectura, todos los atributos esbozados por Maria Kahle, Hans Grimm y Karl May: un lugar distante, extranjero, exótico, la cuestión del Lebensraum, el campesinado y su valentía, el exilio.

Según Coutarde y Cadars, se trata de una película encargada directamente por Goebbels, que se inspiró en El acorazado Potemkin (Bronenosets Potemkin, 1925), de Serguei Eisenstein. Desarrollada como una superproducción, fue la película más importante del período nacional-socialista. ${ }^{25}$

Inspirada también en hechos históricos, la fuente principal fue, sin embargo, una novela, titulada Mann ohne Volk («Hombre sin pueblo», 1934), de Arnold Krieger, un escritor alemán que vivió durante un tiempo en Sudáfrica. 
Sin embargo, aunque el presidente Paul Krüger era un bóer, en esta película representa mucho más al campesino alemán, desde el punto de vista de su mentalidad, su sencillez, sus desgracias, su fuerza física.

Al principio de la película, aparece el presidente, ya muy viejo y enfermo, ingresado en un hospital de Ginebra. Al oír que su país fue derrotado en la guerra contra Inglaterra, comienza a contarle a su enfermera toda la historia en flashback. Explica que sus antepasados se vieron obligados a emigrar porque ya no tenían tierras en su patria y se fueron al extranjero, no para explotar a los nativos pobres, sino para cultivar la tierra. Cuando el protagonista narra el «Gran Viaje», se presenta un paisaje rural vacío en términos de población, un vacío presente también en las narraciones de Maria Kahle y Hans Grimm. Este paraíso no tocado por manos humanas y cultivado por un pueblo trabajador y pacífico es entonces golpeado por los ingleses, el gran antagonista de la trama.

Las tensiones comienzan cuando se descubre oro en Witwatersrand. El gobierno sudafricano aceptó a regañadientes la llegada de inmigrantes, principalmente ingleses.

Pronto surgirán tensiones étnicas entre los bóeres y los británicos, instigadas por estos últimos, interesados en la región. A partir de 1895, los inmigrantes británicos comenzaron a exigir la igualdad de derechos a los bóeres, lo que provocó algunas revueltas que, a partir de 1899, habrían de contar con el apoyo del gobierno británico.

La negación del derecho de voto a los británicos sería el factor decisivo para el comienzo de la guerra anglo-bóer, de la que Inglaterra saldría victoriosa.

Estos son los hechos que componen la trama de la película, que entrelaza lo trágico con escenas divertidas, como la visita del presidente a la reina, dándole recetas de remedios caseros, así como otras escenas que
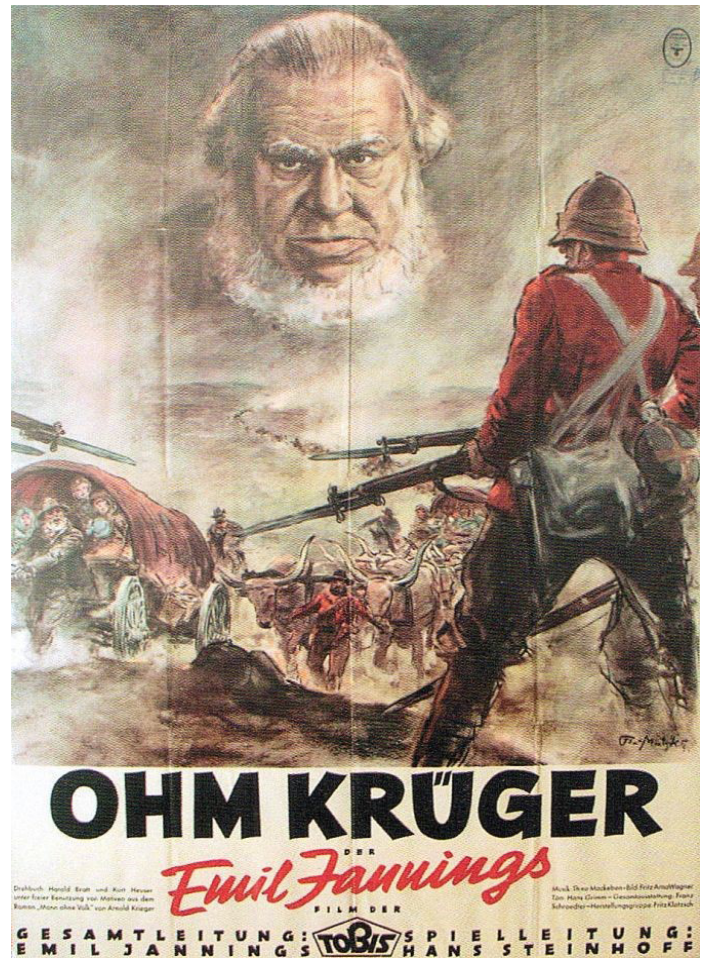

Póster de propaganda del filme Ohm Krüger (Hans Steinhoff, 1941).

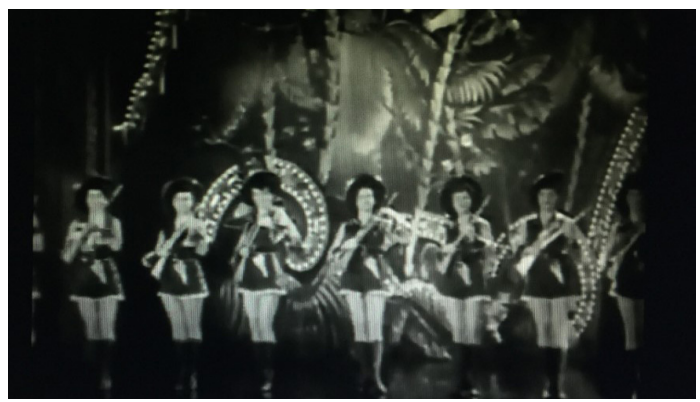

Bailarinas representando a jóvenes bóeres en un cabaret de Paris. Fotograma de Ohm Krüger (1941). ilustran el origen campesino y la personalidad del «tío» Krüger. Hay escenas de cierta frivolidad, como un inusual paso por París del Príncipe de Gales, un disoluto bon vivant que tiene poco interés en la política y se divierte en un cabaret. En él actúan bailarinas con rifles, vestidas de bóeres, afirmando, en la letra de una canción, que se enfrentarán a sus enemigos a su manera, «al modo parisino» («das Klima von Paris»), estribillo que acompaña la escena en la que levantan sus faldas y muestran su trasero.

Sin embargo, las escenas más llamativas son las del conflicto bélico, y no por casualidad. En tiempos de guerra, cuando todo el mundo teme por sus familiares, el cine traslada la muerte y la violencia a otro país, a otro pueblo y a otro tiempo. 
Paul Krüger es una víctima de los ingleses y de los judíos (el personaje de Cecil Rhodes, cuya identidad judía se insinúa, es interpretado por Ferdinand Marian, el mismo actor que encarnó a Joseph Süss Oppenheimer). ${ }^{26} \mathrm{El}$ presidente entiende muy bien cuáles son las intenciones de los ingleses; compran las granjas bóer, envían misioneros para enseñar la fidelidad a la reina, negocian baratijas con los salvajes y les prometen armas, siempre que luchen a favor de «Su Majestad».

Una de las escenas más importantes es la de la rabia de Krüger al notar el intento de levantamiento de una tribu; va al encuentro del cacique Lobenguela, que es sorprendido in fraganti con una casaca del uniforme inglés, aunque medio desnudo de la cintura para abajo. «Haré un tambor con tu piel, negro miserable, si no me dices quién te dio los rifles», amenaza el presidente.

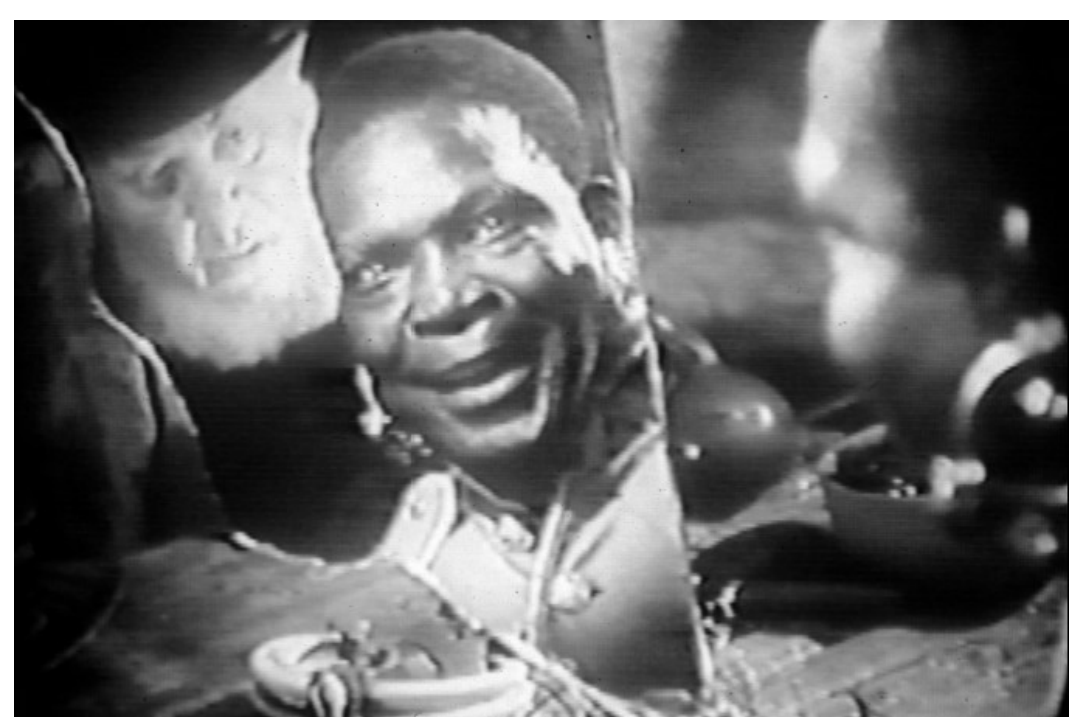

Ohm Krüger llega a la cabaña de Lobenguela. Éste, al verlo por el espejo, esboza una sonrisa entre infantil y de disimulo. Fuente: George Steinmetz y Julia Hell, «The Visual Archive of Colonialism: Germany and Namibia» (Public Culture, 2006), p. 148.

[26] Se trata de una de las películas antisemitas más emblemáticas del periodo nacionalsocialista, $E l$ judio Suss (Jud Sü $\beta$, Veit Harlan, 1940).

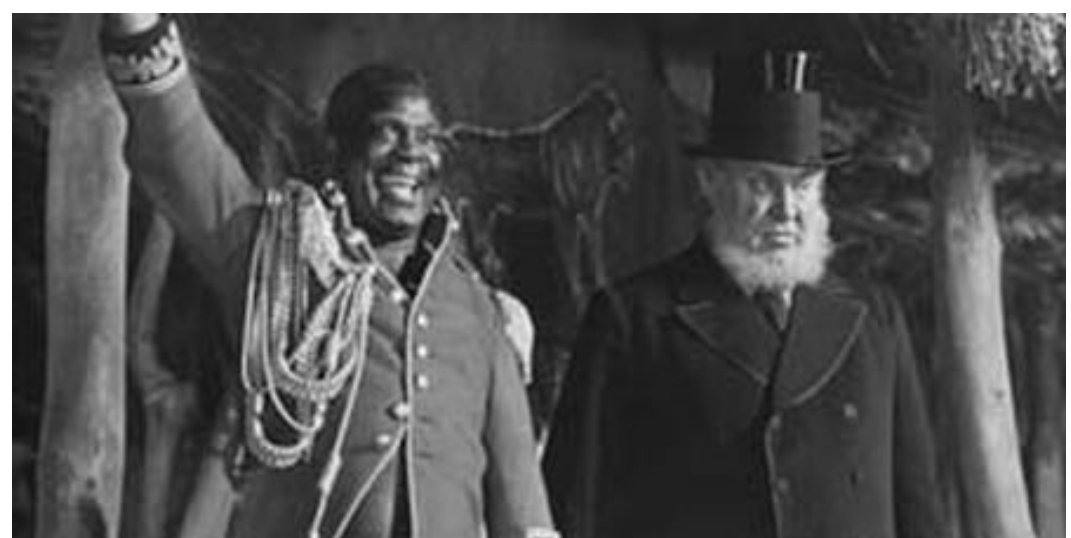

Después de convencer a Lobenguela de quedarse de su lado, el presidente y el cacique calman a la tribu que estaba en pie de guerra. Fotograma de Ohm Krüger. 
Dándose cuenta de todos estos ardides y a pesar de que conoce la fragilidad de su nación, declara la guerra a los ingleses, aun cuando ya está muy viejo y enfermo para tratar de salvar a su terruño.

Con la derrota, la gente es internada en campos de concentración, donde la comida es terrible y donde los cuerpos son enterrados en fosas comunes. Los presos y prisioneros mueren de tifus y de hambre, mientras los soldados se divierten. El hijo de Paul Krüger es ejecutado, sus nietos también mueren, quedando solo su nuera y su esposa, en escenas que parecen tomadas de lo que está sucediendo contemporáneamente en Lídice, Checoslovaquia.

El crepúsculo del pueblo bóer es similar al del campesino alemán, vencido por el capitalismo, por el tratado de Versalles, por las tropas inglesas dondequiera que hubiera alemanes, como en Namibia, que en el momento de rodar la película pertenecía a la Unión Sudafricana, por lo tanto, un dominio del imperio inglés.

La derrota reclamaba venganza, del mismo modo que la Segunda Guerra Mundial podía ser vista por la gente común como la respuesta alemana a lo sucedido en la Primera Guerra Mundial por culpa de los ingleses y los judíos. Y, curiosamente, en las escenas finales, aparecen los campos de concentración como un «espacio de muerte». La postergada venganza, que tanto atormenta a los resentidos ${ }^{27}$ aguarda su revancha bajo la dirección del pueblo fuerte que ha de venir, como profetiza Krüger, ya ciego, en el hospital de Ginebra.

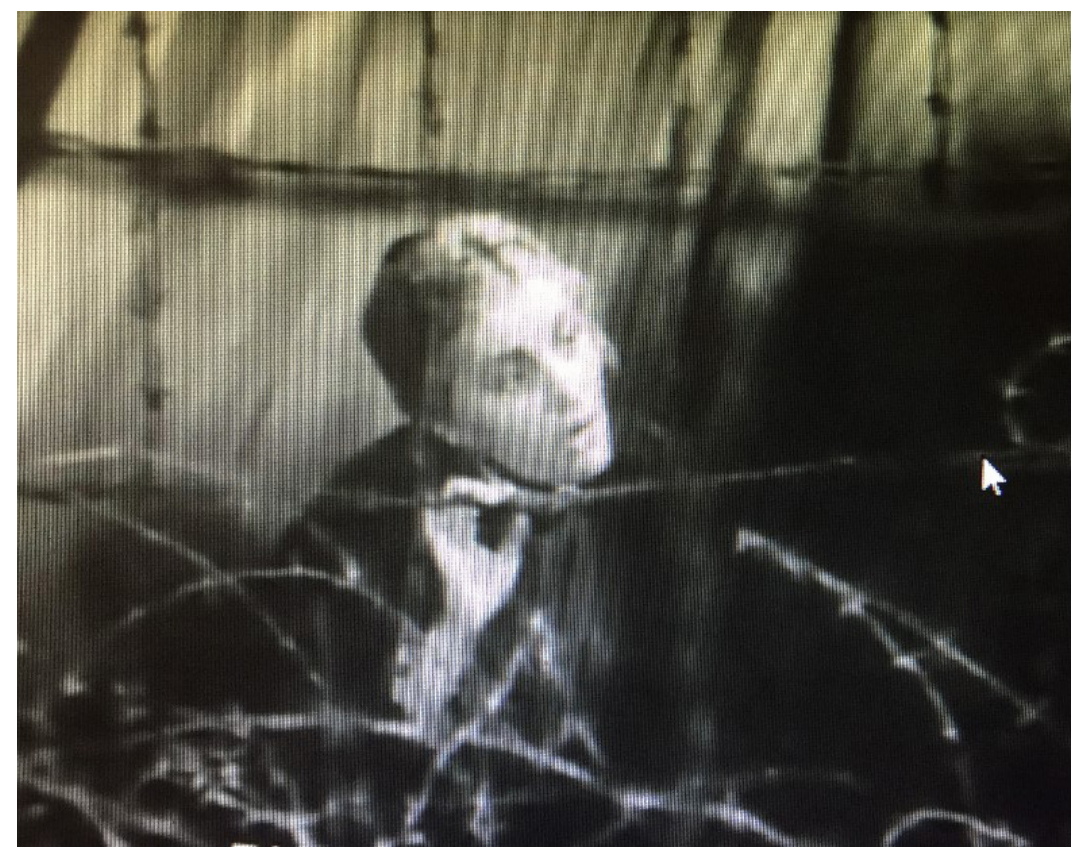

Petra, la nuera de Paul Krüger, en el campo de concentración. Fotograma de Ohm Krüger.

\section{Consideraciones finales}

La era de los imperios se caracterizó, entre otros aspectos, por ser un campo de disputa de opiniones, afectos, recuerdos y mitos fundacionales a través de imágenes
[27] Nos inspiramos aquí en el pensamiento de Pierre Ansart, quien, al reflexionar sobre la Genealogía Moral de Nietzsche, analiza los usos de la Primera Guerra como memoria de la humillación alemana por parte de los nazis. Pierre Ansart, «História e memória dos ressentimentos», en Maria Stela Bresciani y Marcia Naxara (orgs), Memória e ressentimento; indagações sobre uma questão sensível (Campinas, Editora da UNICAMP, 2004), pp. 15-36. 
literarias e iconográficas, culminando en el cine de aventuras que tuvo como escenario lo exótico. En el caso alemán, la cúspide de esta ideología se produjo con el auge del nacional socialismo, cuando las ambiciones expansionistas llevaron a varios segmentos de la población a apoyar la guerra.

El expansionismo también se proyectó para la industria cinematográfica; los nazis se disputaban este sector con los americanos, con la intención de superarlos en calidad y distribución comercial. Para difundir sus películas en América Latina, se apoyaron en las empresas de Buenos Aires, cuyo gobierno esquivaba al liderazgo americano en el continente. En el Brasil, la difusión se hizo desde los consulados y entidades culturales germano-brasileñas. En la Unión Sudafricana contaban una población blanca que simpatizaba abiertamente con el nazismo, considerada como el único gobierno capaz de enfrentarse a sus rivales británicos.

Tocaban la fibra sensible de la población los carteles, textos, portadas de libros, festivales, música, discos, noticias de la radio o de los periódicos que difundían el cine, en cuyas imágenes se mezclaban la ficción y la realidad. Por ejemplo, el mismo año en que se filmaron Ohm Krüger y Carl Peters, se creó un departamento gubernamental para recuperar las colonias africanas que pertenecían a Alemania, acompañado de una intensa propaganda. La Organización Extranjera Alemana del Partido Nazi (Auslandsorganisation der NSDP) envió una expedición a la Amazonia brasileña con el objetivo de conocer mejor la extracción de caucho al mismo tiempo que se exhibía Kautschuk; y los campos de concentración infectados por el tifus, escenificados en la película Ohm Krüger, ya eran una realidad, ahora alemana, una potencia capturada a los británicos para eliminar a sus enemigos.

Lo indiscernible entre el mundo de la vida y la ilusión no era una novedad; después de todo, el cine de entretenimiento, desde sus primeras producciones, bloqueaba la reflexión, ya que el espectador debía atenerse a los veloces mensajes que desfilaban ante sus sentidos «para no perderse en la explosión de los hechos». ${ }^{28}$

La novedad radica en lo exótico ligado tanto al Lebensraum como al Todesraum, y es en este leitmotiv en el he centrado mi atención. En su tiempo libre (Freizeit), el espectador se identificaba con el emigrante, el alemán en el extranjero, transformado en soldado del trabajo, en un territorio imaginado como sustraído de Alemania desde la Primera Modernidad hasta la Primera Guerra Mundial. Lo exótico evoca lo salvaje, el bosque, lo desconocido, pero en la pantalla este mundo distante se hace más cercano, los nativos, más fácilmente domesticables, y la aventura, el deseo suprimido por el monótono trabajo diario, menos imposible, al menos a través de la mirada. El coraje se traduce en fuerza, y el amor, reducido a momentos fugaces y robados, es un objeto al que hay que renunciar a cambio de la victoria. Y así el público pasó por los años de la guerra, preparándose para ella, divirtiéndose, conmoviéndose, conociendo otros mundos, en fin, guardando silencio en su exilio interior.

\section{BIBLIOGRAFÍA}

[28] Theodor Adorno y Max Horkheimer, «A indústria cultural», en Dialética do esclarecimento (Rio de Janeiro, Zahar, 1985), p. 119 ..
Adorno, T., Y Horkheimer, M., Dialética do esclarecimento. (Rio de Janeiro, Zahar, 1985).

AnSART, P., «História e memória dos ressentimentos», en M. Bresciani y M. Naxara (orgs), Memória e ressentimento; indagações sobre uma questão sensível (Campinas, Editora da UNICAMP, 2004), p. 15-36. 
Arendt, H., O sistema totalitário (Lisboa, Dom Quixote, 1978).

BREPOHL, M., Imaginação literária e política; os alemães e o imperialismo (Uberlândia, Editora UFU, 2010).

-, Pangermanismo e nazismo; a trajetória alemã rumo ao Brasil (Curitiba, SAMP, 2014).

—, «Dever de memória e colonialidade: a invisibilidade dos subalternos», en M. Gonçalves y M. Brepohl, Políticas de memória e experiências de (des)exilio (Curitiba, Editora da UFPR, 2017).

Coutarde, F. Y Cadars, P. Histoire du cinéma nazi (Paris, Eric Losfeld, 1972).

D’El ReI, P., Maria Kahle (1891-1975): vida e obra (São Paulo, Instituto Martius-Staden, 2014). Disponible en $:<\mathrm{http} / /$ www.martiusstaden.org.br/ conteudo/detalhe/135/maria-kahle-1891-1975-vida-e-obra> (15/04/2019)

DöBlin, A., Amazonas Trilogie (Munich, Deutsches Taschenbuch, 1991).

Korfman, M. \& Meneguzzo, R., «Encenações autorais e textuais em Karl May» (Pandaemonium ger. vol. 20 n. ${ }^{\circ}$ 31, São Paulo, julio/agosto, 2017).

GlüsIng, J., Das Guyana-Projekt (Berlin, Ch. Links, 2008).

Krachenski Stadler, N., Em busca das colonias perdidas; a visualidade da propaganda do Movimento Neocolonial Alemão (1925-1943) (Tesis de Máster, Curitiba, Universidade Federal do Paraná, 2015).

Nebe, A., «Das Spiel ist aus» (Der Spiegel, 9/02/1950). <https://www.spiegel.de/ spiegel/print/d-44446464.html> (12/09/2019).

Olden, B., Paradiese des Teufels; biographisches und autobiographisches Schriften und Briefen aus dem Exil (Berlin, Rüten\& Loening, 1977).

Pereira, W., O império das imagens de Hitler: O projeto de expansão internacional do modelo nazi-fascista na Europa e na América Latina; 1933-1955 (Tesis doctoral, São Paulo, Universidade de São Paulo, 2008).

Schmitт, C., El nomos de la tierra (Buenos Aires, Ed. Struhart, 2005).

SNYder, L., Macro Nationalisms. A History of the Pan-movements (Londres, Greenwood Press, 1985).

Ueding, R., Karl May Handbuch (Stuttgart, Alfred Kröwer Verlag, 1987).

Steinmetz, G. Y Hell, J., «The Visual Archive of Colonialism: Germany and Nambia» (Public Culture, 18 (1), 2006), p. 132-149.

Recibido: 13 de abril de 2020

Aceptado para revisión por pares: 1 de mayo de 2020

Aceptado para publicación: 29 de junio de 2020 